\title{
INVESTIGATION OF A VARIATIONAL METHOD FOR CALCULATING A STATIONARY MAGNETIC FIELD WITH ALLOWANCE FOR THE ERROR OF THE MAGNETIZATION CHARACTERISTIC
}

DOI: $|0.36724 / 2072-8735-2020-| 4-5-56-6 \mid$

\author{
Robert V. Harutyunyan, \\ Bauman Moscow state technical University, Moscow, Russia, \\ rob57@mail.ru
}

Tigran R. Harutyunyan, JSC " MIC "NPO mashinostroeniya", Moscow region, Reutov, Russia, tigran_20I094@mail.ru

\section{Sergey A. Nekrasov, South Russian state Polytechnic University (NPI), Novocherkassk, Russia, nekrasoff_novoch@mail.ru}

\begin{abstract}
Research on the topic of the article was carried out with the support of the RFBR grant |8-0|-00204 "a"
\end{abstract}

\begin{abstract}
Bilateral methods for calculating the magnetic field characteristics of electrical systems containing ferromagnets and permanent magnets are considered. The methods are based on the application of the Lagrange multiplier method to the electromagnetic field equations in terms of the scalar potential. The study described in the article complements the results of the previous article of the authors devoted to a similar bilateral method based on the Pontryagin maximum principle. The approach based on the Lagrange multiplier method has the advantage that it is applicable for solving both dynamic and stationary problems with distributed parameters. The corresponding conjugate partial differential equations for different optimality criteria (for both uniform and standard metric) are obtained. The solution of the problem of calculation of bilateral estimates of the solution in the calculation of the static magnetic field in a ferromagnet placed in a third-party uniform magnetic field is considered. This method is also applicable for the calculation of the fields of permanent magnets, which requires taking into account the residual magnetization, the final width of the hysteresis loop. For this purpose, the corresponding ratios are given. It is assumed that the main source of error in the calculation is the approximate values of the magnetic permeability of the medium. The obtained results can also be used in solving direct and inverse problems for the system of ferromagnetic bodies and in test problems using other methods.
\end{abstract}

Information about authors:

Robert V. Harutyunyan, Bauman Moscow state technical University, Ph. D., associate Professor of the Department of computational mathematics and mathematical physics, Moscow, Russia

Tigran R. Harutyunyan, JSC " MIC "NPO mashinostroeniya", software engineer, Moscow region, Reutov

Sergey A. Nekrasov, South Russian state Polytechnic University (NPI), doctor of technical Sciences, Professor of the Department of applied mathematics, Novocherkassk, Russia

\section{Для цитирования:}

Арутюнян Р.В., Арутюнян Т.Р., Некрасов С.А. Исследование вариационного метода расчета стационарного магнитного поля с учетом погрешности характеристики намагничивания // Т-Comm: Телекоммуникации и транспорт. 2020. Том I4. №5. С. 56-6I.

For citation:

Harutyunyan R.V., Harutyunyan T.R., Nekrasov S.A. (2020) Investigation of a variational method for calculating a stationary magnetic field with allowance for the error of the magnetization characteristic. T-Comm, vol. I4, no.5, Pp. 56-6I. (in Russian) 


\section{Introduction}

Calculation of electrical systems taking into account the irremediable error is one of the actual applied problems [1-5]. The traditional method that is widely used to account for the error of the coefficients of a mathematical model is the small parameter method [5-7]. The disadvantages of this method are due to the fact that it is asymptotic and not reliable enough, since its accuracy depends significantly on the error value of the original data. Another approach is to use interval analysis methods and two-way methods [9]. However, the corresponding methods are developed primarily for systems with concentrated parameters.

The article develops a corresponding variational approach for the case of distributed magnetostatic systems. Instead of the Pontryagin maximum principle, a more General and practical Lagrange method is used, which is applicable for both dynamic and stationary problems [10]. The advantages of the proposed method are greatest when taking into account the multidimensional functional error.

The article considers as an example a magnetic system consisting of a ferromagnetic material with approximately known characteristics. One of the actual problems of the theory of calculating the magnetic field of electrical devices is related to the influence of the width of the magnetic hysteresis loop of the material on the accuracy of calculating the magnetic field. Accounting for residual magnetization in the model allows calculating systems with permanent magnets [1-4].

\section{Method description}

Let's consider the problem of calculating parameters and characteristics of a stationary magnetic field in a certain magnetic system [1-3]. Assume that a material with magnetic properties (generally speaking, non-uniform with nonlinear and anisotropic properties) occupies volume $V$. Magnetization $\vec{M}$ is related to the induction $\vec{B}$ and strength of the magnetic field $\vec{H}$ according to the vector relation:

$\vec{M}=\vec{B} / \mu_{0}-\vec{H}$, where $\mu_{0}$ is the magnetic permeability of the vacuum. In a non-magnetic medium $\vec{B}=\mu_{0} \vec{H}$, in a ferromagnet $\vec{B}=\mu_{0}(\vec{H}+\vec{M})$. To model the field in a permanent magnet, it is necessary to take into account the residual magnetization $\vec{M}_{n}$ [1]: $\vec{M}=\chi \vec{H}+\vec{M}_{n}$, where $\chi=\mu / \mu_{0}-1$ is the magnetic susceptibility of the material, $\mu$ is the specific magnetic permeability determined in the ferromagnetic region of the main magnetization curve $\mu=\mu(\vec{B})$, and in air, insulation materials and tires $\mu=\mu_{0}, \mathrm{GN} / \mathrm{m}$. Thus, the magnetic permeability and susceptibility in the ferromagnetic region are not constants. For a stationary field, the scalar magnetic potential $\varphi$ is determined : $\vec{H}=-\nabla \varphi$. We assume that the potential is zero at infinity.

Consider the boundary value problem (BVP) for calculating a plane-parallel magnetostatic field in the $X O Y$ coordinate system (the ferromagnet has a prismatic shape, the field sources do not depend on the longitudinal $z$ coordinate). We assume that the magnetic permeability of the volume of ferromagnetic material is several orders of magnitude higher than the magnetic permeabil- ity of air. In this case, the field can be found with very high accuracy using the asymptotic method described in [4]. The intensity in a non-magnetic medium can be represented as: $\vec{H}=\vec{H}_{\text {ст }}-\nabla v$, where $\vec{H}_{\text {ст }}=\vec{H}_{\text {ст }}(x, y)$ is the intensity vector that takes into account the field sources, and is the scalar magnetic potential. The vector $\vec{H}_{\text {ст }}$ can be calculated, for example, using the Bio-Savard-Laplace formula, etc. In a non - magnetic medium, the Laplace equation for the scalar magnetic potential $v$ is solved under the zero boundary condition at the ferromagnetic boundary $\vec{H} \vec{\tau}=0$ or $\frac{\partial v}{\partial \tau}=H_{\text {ст, } \tau}$ (where is the vector tangent to the boundary of the region), taking into account the specified field sources in space. Let's consider an almost important case when $\vec{H}_{\text {ст }}$ we can present it in the form $\vec{H}_{\text {ст }}=-\nabla v_{\text {ст }}$, where $v_{\text {ст }}(x, y)$ - some potential. An example is the problem of finding the field of a ferromagnet placed in a constant third-party field. Then the boundary value problem in a non-magnetic medium has the form:

$$
\Delta v=0,(x, y) \in C \bar{D} ; v=-v_{\mathrm{cT}},(x, y) \in \Gamma=\partial D ;
$$

where $D$ is the region of the magnetic material, $\Gamma$ is its boundary, $C \bar{D}$ is an addition to the set $D+\Gamma$ (the region of the non-magnetic medium).

In the volume of a ferromagnetic body or permanent magnet, the boundary value problem of the second type is solved for the magnetic potential $u$ at a given density of the magnetic flux through the volume boundary:

$$
\begin{aligned}
& \operatorname{div}(\mu(H) \nabla u)=0,(x, y) \in D, \\
& \mu(H) \frac{\partial u}{\partial n}=\mu_{0} \frac{\partial v}{\partial n},(x, y) \in \Gamma ; \\
& u(0,0)=0 ; \vec{H}=-\nabla u,
\end{aligned}
$$

in (3), the derivatives of potentials are written along the normal $\vec{n}$ to the boundary of the region $D$.

It is assumed that the origin of the coordinates belongs to the ferromagnet region. It is necessary to solve the recorded equations taking into account the error of setting the magnetization curve set by the corresponding implementation band:

$$
\mu=\mu(H) \in\left(\mu^{-}(H), \mu^{+}(H)\right),
$$

where $\mu=\mu^{-}(H)$ is the equation of the envelope of the line from below, $\mu=\mu^{+}(H)$ - respectively of the envelope from above, the average value of the permeability is defined as $\mu^{0}(H)=\left(\mu^{-}(H)+\mu^{+}(H)\right) / 2$. Suppose you want to find a lower bound for solving the short-circuit problem at a given point $\left(x_{0}, y_{0}\right)$ in the region $D$ :

$$
u\left(x_{0}, y_{0}\right) \rightarrow \min _{\left(\mu^{-}, \mu^{+}\right)}
$$

(when searching for an estimate from above: $u\left(x_{0}, y_{0}\right) \rightarrow \underset{\left(\mu^{-}, \mu^{+}\right)}{\max }$, where the interval $\left(\mu^{-}, \mu^{+}\right)$denotes the set on which the minimum is found - the band of possible implementations of the magnetization curves (5). 
To solve such problems, the Lagrange multiplier method is widely used $[5,9]$. The Lagrange functional of the problem under consideration has the form:

$$
\begin{aligned}
& L=\iint_{D} w\left(x_{N}, y_{N}\right)\left(\frac{\partial}{\partial x_{N}}\left(\mu\left(\left|\nabla_{N} u\right|\right) \frac{\partial u}{\partial x_{N}}\right)+\frac{\partial}{\partial y_{N}}\left(\mu\left(\left|\nabla_{N} u\right|\right) \frac{\partial u}{\partial y_{N}}\right)\right) d x_{N} d y_{N}+ \\
& +\oint_{\Gamma} w_{1}\left(x_{N}, y_{N}\right)\left(\mu\left(\left|\nabla_{N} u\right|\right) \frac{\partial u}{\partial n_{N}}-\mu_{0} \frac{\partial v}{\partial n_{N}}\right) d \Gamma_{N}+ \\
& +w_{2} u(0,0)+\iint_{D} u\left(x_{N}, y_{N}\right) \delta\left(x_{N}-x_{0}, y_{N}-y_{0}\right) d x_{N} d y_{N},
\end{aligned}
$$

where $w, w_{1}$ - functional Lagrange multipliers, $w_{2}-$ numerical Lagrange multiplier, $\delta$ - Delta function $[6,7]$.

The first integral in this functional is converted to the form

$$
\oint_{\Gamma} w\left(x_{N}, y_{N}\right) \mu_{0} \frac{\partial v}{\partial n_{N}} d \Gamma_{N}-\iint_{D} \mu\left(\left|\nabla_{N} u\right|\right) \nabla_{N} u \nabla_{N} w d x_{N} d y_{N} .
$$

To solve the problem, according to the known method, the variation of the function $u$ is calculated and the equation of extremals of this functional is found [6-7, 9].

The values corresponding to the lower (or upper) estimation of the solution are found from the condition of the extremum of the Lagrange functional: $L \rightarrow \min$ (or $L \rightarrow \max$ ), for all $\mu(|\nabla u|)$ of the admissible set (5). The extreme value in the top estimation is reached if the magnetic characteristic is described by the expression

$$
\mu^{*}=\mu^{0}(|\nabla u|)(1-0.5 \varpi(|\nabla u|) \operatorname{sign}(\nabla u \nabla p))
$$

(when evaluating from below, the " - "sign in the formula changes to"+"), $\varpi(H)$ - the relative error of setting the magnetization curve at the $H$-strength, $p$ - the solution of the conjugate system of the Lagrange method, which is found by the standard method $[5,9]$ and has the form:

$$
\begin{aligned}
& \operatorname{div}\left(\mu^{*}(|\nabla u|) \nabla p+H^{-1} \frac{d \mu^{*}}{d H}(\nabla u \nabla p) \nabla u\right)+. \\
& +\delta\left(x-x_{0}, y-y_{0}\right)-\delta(x, y)=0,(x, y) \in D . \\
& \left(\mu^{*}(|\nabla u|) \nabla p+H^{-1} \frac{d \mu^{*}}{d H}(\nabla u \nabla p) \nabla u, \vec{n}\right)=0,(x, y) \in \Gamma,
\end{aligned}
$$

where $\vec{n}$ is the normal vector to the boundary of area $D$.

If you want to estimate a standard error instead of a uniform one, for example

$$
\left\|u-u^{0}\right\|_{L_{2}(D)} \rightarrow \min \text { or }\left\|u-u^{0}\right\|_{L_{2}(D)} \rightarrow \max ,
$$

then, instead of (8), use the equation:

$$
\operatorname{div}\left(\mu^{*}(|\nabla u|) \nabla p+H^{-1} \frac{d \mu^{*}}{d H}(\nabla u \nabla p) \nabla u\right)+C_{0}\left(u-u^{0}\right)=0,(x, y) \in D,
$$

where $u^{0}$ is the BVP solution when the average line of the band (5) corresponding to the arithmetic mean of the lower and upper estimates of magnetic permeability is selected as the magnetization characteristic. The coefficient $C_{0}$ can be chosen to be equal to one (it is used for matching the dimensions of the terms in the equation). The numerical solution of this problem about the standard error is supposed to be considered in the following articles of the authors. Nevertheless, the equations of the corresponding BVP are given for methodological purposes to illustrate the broad possibilities of the proposed approach.

Using the known standard finite difference methods [6,7], the computational domain and differential equations are discretized (1)-(3), (8) and (9) we obtain a system of nonlinear equations:

$$
\begin{aligned}
& \Delta_{h} v_{h}=0,\left(x_{h}, y_{h}\right) \in C \bar{D}_{h} ; v_{h}=-v_{\text {ст, },},\left(x_{h}, y_{h}\right) \in \Gamma_{h}, \\
& \operatorname{div}_{h}\left(\mu\left(H_{h}\right) \nabla_{h} u_{h}\right)=0,\left(x_{h}, y_{h}\right) \in D_{h}, \\
& \left(\mu^{*}\left(\left|\nabla_{h} u_{h}\right|\right) \nabla_{h} u_{h}-\mu_{0} \nabla_{h} v_{h}\right) \cdot \vec{n}_{h}=0,\left(x_{h}, y_{h}\right) \in \Gamma_{h}, \\
& \operatorname{div}_{h}\left(\mu^{*}\left(\left|\nabla_{h} u_{h}\right|\right) \nabla_{h} p_{h}+H_{h}^{-1} \frac{d \mu^{*}}{d H}\left(\nabla_{h} u_{h} \nabla_{h} p_{h}\right) \nabla_{h} u_{h}\right)+ \\
& \delta_{h}\left(x_{h}-x_{0}, y_{h}-y_{0}\right)-\delta_{h}\left(x_{h}, y_{h}\right)=0,\left(x_{h}, y_{h}\right) \in D_{h} \\
& \left(\mu^{*}\left(\left|\nabla_{h} u_{h}\right|\right) \nabla_{h} p_{h}+H_{h}^{-1} \frac{d \mu^{*}}{d H}\left(\nabla_{h} u_{h} \nabla_{h} p_{h}\right) \nabla_{h} u_{h}, \vec{n}_{h}\right)=0,\left(x_{h}, y_{h}\right) \in \Gamma_{h},
\end{aligned}
$$

where $h$ is a parameter of the grid partition of the region, the index $h$ marks the grid analogs of the corresponding continuous quantities and operators, and the boundary values of the grid functions. BVP (1)-(9) was approximated with the second order of accuracy on $h$ both in the region and on the border.

The problem of the Lagrange method (1)-(9) is solved iteratively:

1. Sets the initial approximation for the magnetization curve (usually the median line of the band (5)). The solution of the conjugate BVP is assumed to be zero at the beginning in area $D$.

2. The external and internal short circuits for calculating the magnetic field are solved for a certain approximate solution of the conjugate problem (8)-(9) and the corresponding approximate value $\mu^{*}$ calculated according to the formula (7).

3 . The conjugate BVP (8)-(9) is solved when the value is recalculated according to the results of item $2 \mu^{*}$ and the approximate solution of the field BVP (1)-(4) is refined.

4. $\mathrm{V}$ ues $u\left(x_{0}, y_{0}\right)$ are compared in two iterations. If the specified accuracy is not reached, the iterations continue with the transition to step 2.

The computational process of solving such problems is described in detail and mathematically investigated in the article [10]. An example of an alternative solution method is an approach based on interval estimates [9].

\section{An example of calculating the two-sided estimates for solutions of equations of magnetostatics in ferromagnetic}

Consider the case of a ferromagnet in the form of a parallelepiped (Fig. 1), located in a uniform third-party magnetic field with an induction of $\mathrm{B}_{0}=0.8 \mathrm{~T}$, directed along the $O Y$ axis and inducing a field in a ferromagnet. BVP will take the form (1) at $v_{\text {ст }}=-B_{0} / \mu_{0} y$. It is necessary to find two-way estimates of the solution at a given point $\left(x_{0}, y_{0}\right)$ in the region $D$, taking into account the known error of the magnetization characteristic set using the function $\varpi(B)$ (see formula (7)). In calculations, the 
half size of the sides of the cross-section of a parallelepiped made of ferromagnetic material is assumed to be equal to one $L_{x}=1, L_{y}=1$ ( Fig. 1).

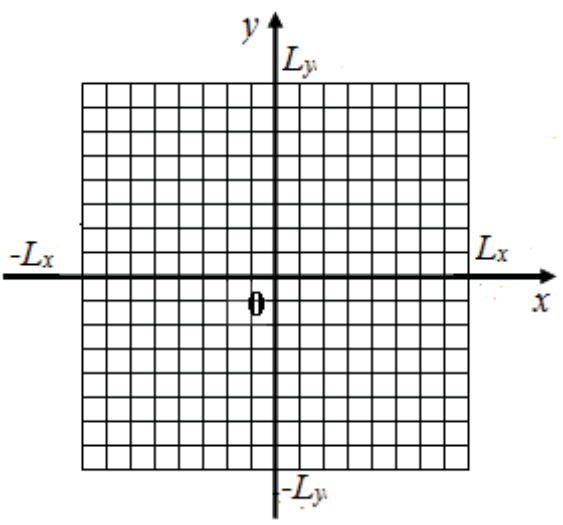

Fig. 1. The cross section of a ferromagnetic parallelepiped by the $X O Y$ plane and the corresponding grid area at $n_{x}, n_{y}=8$

The results of calculations using the finite difference method for the number of partitions along the coordinate axes of the ferromagnet region are given below: $n_{x}, n_{y}=5$. The size of the cells $h_{x}=L_{x} / n_{x}, h_{y}=L_{y} / n_{y}$. The size of the calculated area was selected 5 times larger for the same grid steps. An example of the grid region is to divide the cross-section of a ferromagnet on a square cell whose vertices are the nodes of the mesh depicted in Fig. 1.

The main magnetization curve is calculated using the Langevin formula $M_{f}(H)=M_{s}(\operatorname{cth}(H / a)-a / H)$, the parameters $M_{s}, a$ are determined by the material. The parameter values for e330a electrical steel are $M_{s}=1648136.0 ; a=55.2$. The error of setting the magnetization curve in the calculations was assumed to be $5 \%(\varpi(H)=0,1)$. The results of calculating uniform estimates of the solution from the top and bottom are given in the table. Negative values $\varpi(H)$ correspond to the rating from below, positive values $\varpi(H)$ correspond to the rating from above.

The accuracy of solution of the difference equations is of the order of $10^{-4} \ldots 10^{-5}$. The solution was found by an iterative relaxation method (the relaxation coefficient is 0.1 ).

As shown by the results of solving the Lagrange multiplier method, presented in the table, for all the considered points of the region, the property of bilaterality of estimates has been preserved, i.e., the qualitative correspondence of theoretical and numerical two-way estimates (due to the sampling error of the problem, such violations can occur when the region is divided too roughly). Therefore, the results shown in the table show that the two-way method considered in the article is practically acceptable.

For Fig. 2 and 3 show a series of unit-normalized graphs that characterize the dependence of the $y$ parameters of the magnetic field in the air and in the ferromagnetic region with a step $h_{x}$ along the abscissa axis $\left(x=-h_{x} n_{x}, \ldots, h_{x} n_{x}\right)$. For Fig. 2 on the vertical axis, the value of the scalar magnetic potential $u_{\max }=10^{6}$ $\mathrm{A}$ is taken as a unit, and on the horizontal axis $-y_{\max }=1.5 L_{y}$. The use of two scales is related to the requirements of drawing clarity.
Table

The results of the decision circuit

\begin{tabular}{|c|c|c|c|c|c|}
\hline$\langle|\mathrm{p}|\rangle$ & $\mathrm{ax}|\mathrm{p}|$ & $\varpi(H)$ & $x_{0}$ & $y_{0}$ & $u\left(x_{0}, y_{0}\right)$ \\
\hline 1964.85007 & 1988.31583 & -0.10 & -5 & -5 & 262.79312 \\
\hline 2043.21236 & 2066.63434 & 0.10 & -5 & -5 & 647.81461 \\
\hline 4614.15949 & 4641.52274 & -0.10 & -4 & -4 & 169.43313 \\
\hline 4126.44905 & 4152.71996 & 0.10 & -4 & -4 & 333.67402 \\
\hline 4806.65968 & 4835.36997 & -0.10 & -3 & -3 & 121.60234 \\
\hline 4303.07974 & 4344.20867 & 0.10 & -3 & -3 & 223.87075 \\
\hline 4897.80009 & 4925.72391 & -0.10 & -2 & -2 & 76.25577 \\
\hline 4473.04123 & 4521.28807 & 0.10 & -2 & -2 & 140.02441 \\
\hline 4960.69039 & 4980.30642 & -0.10 & -1 & -1 & 35.35703 \\
\hline 5155.11358 & 5202.20330 & 0.10 & -1 & -1 & 76.23501 \\
\hline 5050.67244 & 5060.37790 & -0.10 & 0 & 0 & 0 \\
\hline 5256.78002 & 5286.14070 & 0.10 & 0 & 0 & 0 \\
\hline 5083.89098 & 5094.31434 & -0.10 & 1 & 1 & -53.39003 \\
\hline 5346.43769 & 5367.48972 & 0.10 & 1 & 1 & -47.88603 \\
\hline 5196.13915 & 5216.94888 & -0.10 & 2 & 2 & -105.93750 \\
\hline 5506.17150 & 5532.85193 & 0.10 & 2 & 2 & -93.66607 \\
\hline 5270.42920 & 5297.91971 & -0.10 & 3 & 3 & -145.01243 \\
\hline 5615.00142 & 5646.95074 & 0.10 & 3 & 3 & -118.71798 \\
\hline 5426.90117 & 5455.84568 & -0.10 & 4 & 4 & -336.16334 \\
\hline 5694.49215 & 5720.20326 & 0.10 & 4 & 4 & -173.69809 \\
\hline 5501.54560 & 5525.75066 & -0.10 & 5 & 5 & -647.81466 \\
\hline 5788.50031 & 5812.24166 & 0.10 & 5 & 5 & -262.79313 \\
\hline
\end{tabular}

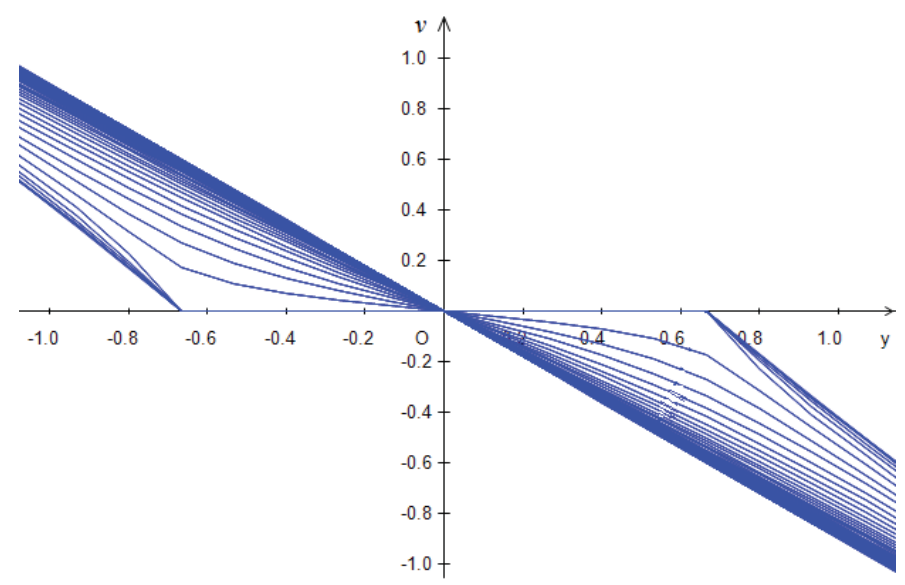

Fig. 2. Graphs of the dependence of the scalar magnetic potential in air from the ordinate at fixed abscissa values (scales on the ordinate axis $1: 7.5$ and on the vertical axis $1: 2 / 3$ )

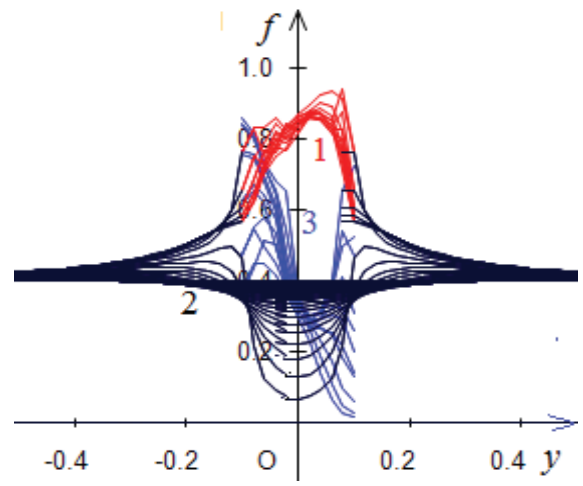

Fig. 3. Graphs of magnetic induction after 10 iterations in the magnet (1), in the air (2) and specific magnetic conductivity (3) (scales on the vertical axis for a series of graphs (1) and (2) - 1:2, for a series of graphs (3) $\left.-1: \mu(0) \approx 10^{4} \mu_{0}\right)$, $\varpi(H)=-0,1$ 
For Fig. 3 for a unit on the vertical axis for induction graphs, the value $B_{\max }=2,5 B_{r}$ is taken, and on the horizontal axis, respectively, the value $y_{\max }=10 L_{y}$. The asymmetry of the graphs in Fig. 3 is related to the special feature of the Lagrange multiplier method-estimates are found at the top (bottom), which affects the symmetry of the solution of the problem.

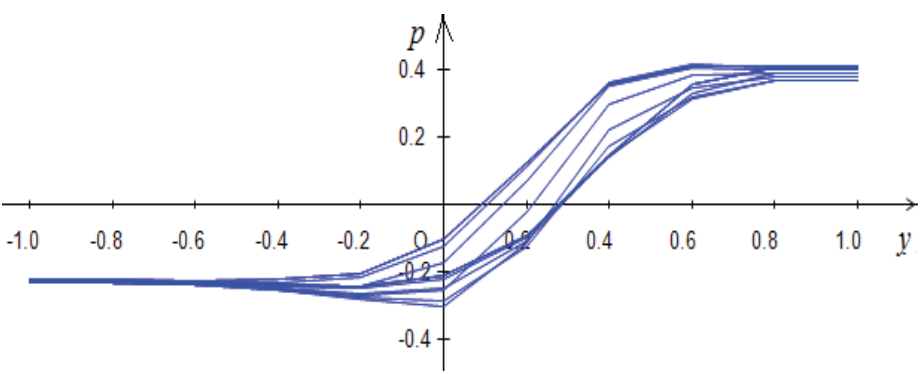

Fig. 4. Graphs of the solution of the conjugate BVP after 10 iterations (in relative coordinates)

For Fig. 4 graphs of the solution of the conjugate BVP in relative coordinates are given (the graphs are normalized to a value of 1500, approximately equal to the average absolute value of the function $p$ for the region, the value $y_{\max }=L_{y}$ is taken as a unit along the horizontal axis).The described method can be used for solving both stationary and dynamic problems, taking into account the error of the coefficients [10], but for non-stationary short circuits, a two-way method based on the Pontryagin maximum principle successfully competes with the Lagrange multiplier method [4].

\section{Conclusion}

A new two-way method is proposed for calculating the characteristics of the stationary magnetic field of electrical systems containing ferromagnets and (or) permanent magnets, taking into account the error of the magnetization characteristic. The method is based on applying the Lagrange multiplier method to magnetic field equations in terms of scalar potential. It is assumed that the main source of error in the calculation is the approximate values of the magnetic permeability of the medium. In comparison with the common small parameter method, the limit on the error value of the parameters and characteristics of the boundary value problem is much smaller, which greatly expands the range of problems to be solved. Although the article considered an example of a plane-parallel field, the idea and basic relations of the method remain unchanged for three-dimensional problems of the magnetic field theory. The method is also applicable for solving non-stationary problems with an irremediable error. The corresponding problems include estimates of switching overvoltages, current surges when switching on circuits with nonlinear inductances.

The proposed method has advantages in solving problems in which it is necessary to find solution estimates in the vicinity of a finite number of singular points. As shown, it is possible in principle to estimate the standard error of the solution in the entire domain. Relevant examples are direct and inverse problems for calculating permanent magnets, and evaluating the effect of the hysteresis loop width. The method can be used to improve the reliability of results in design calculations of various electrical devices, as well as in problems of the theory of magnetic measurements.

\section{References}

1. Blokh .I. (2012). Theoretical foundations of integrated magnetic prospecting. Moscow: MGAU. 160 p. From the site sigma3d.com

2. Haru unyan R.V., Nekrasov S.A., Seredina P.B. (2018). Identification of the magnetization of permanent magnets based on the scalar magnetic potential method. Izv. universities. Electromechanics. Vol. 61. No. 6. P. 19-25. DOI: 10.17213 / 0136-3360-2018-6-19-2 5

3. Haru unyan R.V., Nekrasov S.A., Sereduna P.B. (2019). Identification methods for magnetization of permanent magnets based on integral equations. Research and application examples. Izv. universities. Electromechanics. No. 1.

4. Haru unyan T.R., Nekrasov S.A. (2019). Two-way method for calculating dynamic electrical systems with distributed parameters, taking into account the error of the initial data. higher educational. Electromechanics. Vol. 62. No. 2. P. 5-13.

5. Directory for automatic councils leniyu. (1987). Ed. AA. Krasovsky. Moscow: Science. 712 p.

6. Korn T., K n T. (1978). Handbook of mathematics. Moscow: Science. 832 p.

7. Trenogin V.A. (1980). Functional analysis. Moscow: Science. $496 \mathrm{p}$.

8. Vasilyev O.V. (1978). The principle of maximum Pontryagin in theory optimal systems with distributed parameters. Applied Mathematics. Novosibirsk. P. 109-138.

9. Rogalev A.N. (2004). Boundaries of sets of solutions of systems of ordinary differential equations with interval initial data. Cотриting technology. Vol. 9. No. 1. P. 86-94.

10. Nekrasov S.A. (2018). Solution of Boundary Problems with Regard for Inherent Error on the Basis of the Lagrange Method. Automation and Remote Control. Vol. 79. Issue 11. P. 2018-2032. 
ИССЛЕДОВАНИЕ ВАРИАЦИОННОГО МЕТОДА РАСЧЕТА СТАЦИОНАРНОГО МАГНИТНОГО ПОЛЯ С УЧЕТОМ ПОГРЕШНОСТИ ХАРАКТЕРИСТИКИ НАМАГНИЧИВАНИЯ

Арутюнян Роберт Владимирович, Московский государственный технический университет имени Н.Э.Баумана, Москва, Россия, rob57@mail.ru

Арутюнян Тигран Робертович, АО "ВПК "НПО машиностроения", Московская область, г. Реутов, Россия, tigran_20I094@mail.ru Некрасов Сергей Александрович, Южно-Российский государственный политехнический университет (НПИ),

2. Новочеркасск, Россия, nekrasoff_novoch@mail.ru

\section{Аннотация}

Рассмотрены двусторонние методы расчета характеристик магнитного поля электротехнических систем, содержащих ферромагнетики и постоянные магниты. Методы основаны на применении к уравнениям электромагнитного поля в терминах скалярного потенциала метода множителей Лагранжа. Исследование, описанное в статье, дополняет результаты предыдущей статьи авторов, посвященной двустороннему методу на основе принципа максимума Понтрягина. Подход на основе метода множителей Лагранжа имеет то преимущество, что он применим для решения как динамических, так и стационарных задач с распределенными параметрами. Получены соответствующие сопряженные уравнения в частных производных для разных критериев оптимальности (как для равномерной, так и среднеквадратической метрики). Рассмотрено решение задачи расчета двусторонних оценок решения при расчете статического магнитного поля в ферромагнетике, помещенном в стороннее равномерное магнитное поле. Данный метод применим и для расчета полей постоянных магнитов, для чего требуется учитывать остаточную намагниченность, конечную ширину петли гистерезиса. Для этой цели приведены соответствующие соотношения. Предполагается, что при расчете основным источником погрешности являются приближенные значения магнитной проницаемости среды. Полученные результаты могут использоваться также при решении прямых и обратных задач для системы ферромагнитных тел и в тестовых задачах при использовании других методов.

Ключевые слова: расчет магнитного поля, двусторонний метод, погрешность коэффициентов, ферромагнетики, постоянные магниты, скалярный и векторный магнитные потенциалы, метод множителей Лагранжа.

\section{Литература}

І. Блох Ю.И. Теоретические основы комплексной магниторазведки. М.: МГГА, 2012. 160 с. PDF. С сайта sigma3d.com.

2. Арутюнян Р.В., Некрасов С.А., Середина П.Б. Идентификация намагниченности постоянных магнитов на основе метода скалярного магнитного потенциала // Изв. вузов. Электромеханика. 20I8. T. 6I, № 6. C. 19-25. DOI:10.172I3/0I36-3360-2018-6-19-25.

3. Арутюнян Р.В., Некрасов С.А., Середина П.Б. Методы идентификации намагниченности постоянных магнитов на основе интегральных уравнений. Исследование и примеры применения // Изв. вузов. Электромеханика. 2019. № I.

4. Арутюнян T.P., Некрасов С.А. Двусторонний метод расчета динамических электротехнических систем с распределенными параметрами с учетом погрешности исходных данных // Изв. вузов. Электромеханика. 2019. Т. 62. №2. С. 5-І3.

5. Справочник по автоматическому управлению / Под ред. А.А. Красовского. М.: Наука, 1987. 7 /2 с.

6. Корн Г., Корн Т. Справочник по математике. М.: Наука, 1978. 832 с.

7. Треногин В.А. Функциональный анализ. М.: Наука, 1980. 496 с.

8. Васильев Ф.П. Численные методы решения экстремальных задач. М.: Наука, 1988. 552 с.

9. Рогалев А.Н. Границы множеств решений систем обыкновенных дифференциальных уравнений с интервальными начальными данными // Вычислительные технологии. 2004. Т. 9. № І. С. 86-94.

10. Nekrasov S.A. Solution of Boundary Problems with Regard for Inherent Error on the Basis of the Lagrange Method // Automation and Remote Control. November 2018. Vol. 79. Issue II, pp. 2018-2032.

Информация об авторах:

Арутюнян Роберт Владимирович, Московский государственный технический университет имени Н.Э.Баумана, к.ф.-м.н., доцент кафедры вычислительной математики математической физики, Москва, Россия

Арутюнян Тигран Робертович, АО "ВПК "НПО машиностроения", инженер - программист, Московская область, г. Реутов, Россия

Некрасов Сергей Александрович, Южно-Российский государственный политехнический университет (НПИ), д.т.н., профессор кафедры прикладной математики, г. Новочеркасск, Россия 